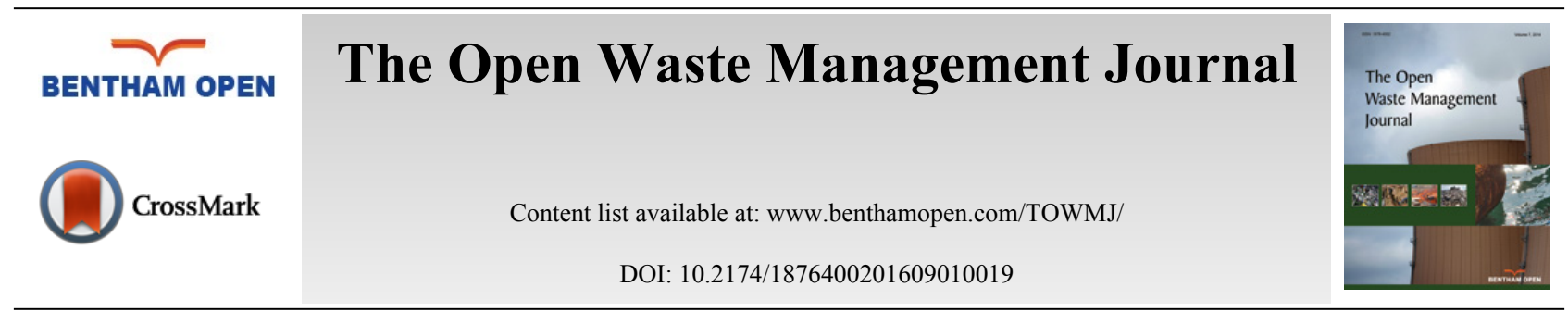

RESEARCH ARTICLE

\title{
Characterisation of Municipal Solid Waste for Planning Sustainable Waste Management in Kumba Municipality - South Western Cameroon
}

\author{
E.B. Tambe ${ }^{\mathrm{a}}$, G.C. Ayongwa ${ }^{\mathrm{a}, \mathrm{b}}$, N.M. Ngwabie ${ }^{\mathrm{b},{ }^{*}}$ and G.T. Forbid ${ }^{\mathrm{a}}$ \\ ${ }^{a}$ Higher Institute of Agriculture and Rural Development, Bamenda University of Science and Technology, P.O Box 277, \\ Bamenda, Cameroon \\ ${ }^{b}$ Department of Agricultural and Environmental Engineering, University of Bamenda, Cameroon
}

Received: December 15, 2015

Revised: February 18, 2016

Accepted: September 08, 2016

\begin{abstract}
Municipal solid waste (MSW) characterisation across socioeconomic residents is necessary for planning sustainable solid waste management. In view of planning for Kumba municipality in the South West Region of Cameroon, three types of socioeconomic residents classified as low, medium and high income residential areas were randomly sampled. In each residential area, 32 households were sampled following systematic random sampling. Over a period of eight weeks within three periods characterised with varying activities, statistically designed number of samples for waste composition were hand sorted and weighed at source of generation. The study revealed that the per capita generation of putrescible and miscellaneous wastes (predominantly sand, ash and dust) were statistically different $(\mathrm{p}<0.05)$ across residents and were inversely related to income while the generation of plastics, metals, papers, glass except textiles were statistically different across residents and were positively related to income. Putrescible waste was the most predominant waste category constituting more than $75 \%$ across residents. No significant differences were observed for per capita waste generation across residents during the entire period of study and within residents during the different periods over which the waste categories were measured. However, within the different periods, waste generation was significantly different across residents with more waste being produced in low income residents. The waste density was found to decrease with increasing income. The observed variation of waste generation and composition has implications for collection frequency, equipment needs, composting and digestion of the biodegradable for biogas generation to sustain the solid waste management sector.
\end{abstract}

Keywords: Characterisation, Developing countries, Integrated management, Municipal solid waste, Socioeconomic levels.

\section{INTRODUCTION}

Waste generation is an attribute of every life and a human being ceases to generate waste only when he is no more and is to be disposed as waste [1]. The quantity and quality of municipal solid waste (MSW) generated varies in space and time with the variation attributed to rising consumer attitude, population growth, seasonality and development of technologies [2 - 5]. Several authors have found that the per capita MSW generation, the quantity of waste produced by one person in one day, is positively related to income levels of the people in the community $[2,6,7]$. The composition of MSW generated varies with the income level of the community or residential area [5, 8]. The proportion of biodegradable content in waste generated in developing countries is higher than that generated in developed countries although the total amount of biodegradable waste remains higher in high income economies [4, 9]. For example, countries in East Asia and Pacific (EAP) region have the highest proportion of biodegradable waste (putrescible) at $62 \%$ while the Organisation for Economic Co-operation and Development (OECD) countries with a relatively lower

\footnotetext{
* Address correspondence to this author at the Department of Agricultural and Environmental Engineering, University of Bamenda, Box 39 Bambili, Cameroon; Tel: +237671643209; E-mail: ngwabie@yahoo.co.uk
} 
population have the least at $27 \%$, although the total amount of biodegradable waste is still highest in OECD countries [4].

The volume of solid waste generated has continually increased at a faster rate than management resources, resulting to indiscriminate disposal and mal-practices which tend to endanger human health and the environment [10 - 13]. The rudimentary nature of MSW characterisation data, especially in developing countries $[14,15]$ makes waste management more difficult. Besides the absence of data, waste management solutions in developing countries are usually constrained by financial deficiencies, lack of policy implementation and inefficient community participation [14, 16 - 18].The availability of data on MSW characterisation is the first vital step in developing an integrated solid waste management plan, an approach which seeks to protect human health and the environment [15, 19]. With available data, a welldesigned MSW management scheme could promote the quality of urban environment, generate employment and income, protect environmental health and support the efficiency and productivity of the economy [20].

However, there is little or no information yet on the characterisation of MSW in most urban communities of Cameroon and in particular the South West Region. In addition, waste collection frequency by the management authorities in most cities in Cameroon is not commensurate to waste generation resulting to wanton disposal. This paper aims to quantitatively and qualitatively characterise MSW generated in three socioeconomic levels in the municipality and at different periods in order to assist the management authority in developing an integrated municipal solid waste management scheme.

\section{MATERIAL AND METHODS}

\subsection{Study Area}

Municipal solid waste was characterised in Kumba which is the head quarter of Meme Division in the South West Region of Cameroon. It is the largest city in the region and according to the Kumba City Council ${ }^{1}$, the population of the municipality was estimated at 450,000 inhabitants in 2014, spread across a surface area of $186 \mathrm{~km}^{2}$. The equatorial location of the municipality, coupled with its rich volcanic soil has favoured many large agro-industrial establishments. Its proximity to the Nigerian border and a home for many financial and educational institutions has also enhanced its commercial activities.

\subsection{Sampling Procedure}

The sample unit for waste generation and income level was the household. Standard of housing infrastructure was used to delineate income levels of households and classified into strata [5, 7, 19, 21]. In this regard, three strata were identified:

1. Low income residential areas (LIRA): Illegal and non-permanent structures or houses in unplanned and squatter settlements and occupied by poor families with very low income.

2. Medium income residential areas (MIRA): High rise buildings or multiple occupancy properties with no gardens and close to shopping centres or the central business district.

3. High income residential areas (HIRA): Single detached houses outside the city centre with gardens.

As households could not disclose their income levels, proxies of income such as educational attainment, number of people working in a household and earning an income and the type of job involved were used in the field to assist in affirming income levels of the three socioeconomic residential areas [7, 21].

The study chose 96 households equally shared among the strata (32 households for each income level residential area). Eighty two (82) households participated with a population of 474 people in the study period of eight weeks with the number of samples for waste categories for low, medium and high income residential area being 213,181 and 195 respectively (Table 1). This corresponds to $90 \%$ confidence level (CL) for number of samples in waste characterisation study $[15,22]$. The sample size was reasonably large as the CL for solid waste characterisation data are usually set at $80 \%$ or $90 \%$ [22].

\footnotetext{
${ }^{1}$ Archives, Administrative account of 2014, personal communication with Chief of Cabinet and Director of Administrative Affairs and Finance of the Kumba City Council.
} 
Table 1. Household units following areas of residence.

\begin{tabular}{|l|c|c|c|c|}
\hline Residential Areas & $\begin{array}{c}\text { Number of households } \\
\text { contacted }\end{array}$ & $\begin{array}{c}\text { Number of households that } \\
\text { participated }\end{array}$ & $\begin{array}{c}\text { Number of Persons that } \\
\text { Participated }\end{array}$ & $\begin{array}{c}\text { Number of each waste } \\
\text { category }\end{array}$ \\
\hline LIRA & 32 & 28 & 165 & 213 \\
\hline MIRA & 32 & 27 & 136 & 181 \\
\hline HIRA & 32 & 27 & 173 & 195 \\
\hline Total & 96 & 82 & 474 & 589 \\
\hline
\end{tabular}

\subsection{Data Collection and Analysis}

Occupants in the households that were sampled were educated on the research objectives. Each household was provided a labelled plastic bag in which the different waste samples were to be collected. Hand sorting of waste at the primary stage of waste generation was conducted in order to improve the accuracy of the data collected [15]. Once every week, the households were visited and wastes samples in the labelled bags were collected and manually sorted according to the profile in Table 2.

Table 2. Household waste composition profile considered in the survey.

\begin{tabular}{|l|l|}
\hline Categories & \multicolumn{1}{|c|}{ Sub-categories } \\
\hline Putrescibles & Food remnants, fresh and decaying leaves, vegetation, garden wastes \\
\hline Plastics & Plastic bottles, packaging materials \\
\hline Metals & Cans, bottle caps, ferrous metals, aluminium items \\
\hline Papers & Newspapers, magazines, office papers, junk mails, envelopes \\
\hline Glass & Glass, bottles, jars \\
\hline Textile & Clothes, belts, shoes \\
\hline Miscellaneous & Wood, stones, pebbles, waste electrical and electronic equipment, batteries, ash, dust, sand \\
\hline
\end{tabular}

Source: Adapted from [5].

Each category of waste was weighed to the closest \pm 50 grams using a sensitive spring scale balance and the values were registered in a data sheet. The number of people living in the house at the time of the study was recorded weekly. Data was collected for 8 weeks from $6^{\text {th }}$ December 2013 to $28^{\text {th }}$ January 2014 . Data collection was categorised into three periods presumed to be different in economic activities and consumption habits. The Christmas period was used as a reference for the periods following its observed exceptional food preparation, increasing purchasing power of households, sharing of gifts among others and its relation with waste generation when compared with other periods before and after Christmas. Period $1\left(\right.$ week $1 \& 2$ ): $6^{\text {th }}$ to $17^{\text {th }}$ December 2013 - before Christmas; Period 2 (week 3 , 4 \& 5): $18^{\text {th }}$ December 2013 to $7^{\text {th }}$ January 2014 - within Christmas; Period 3 (week 6, $7 \& 8$ ): $8^{\text {th }}$ to $28^{\text {th }}$ January $2014-$ after Christmas. Structured questionnaire was used to collect data to elucidate the following: per capita waste generated, socioeconomic characteristics, current waste management practices among others.

Waste density for each residential area was determined by stuffing the waste bags of known dimension and dividing the stuffed weight by the total volume [23]. The per capita waste generated was calculated by dividing the mass of the total waste generated by the number of days used to generate the waste, then dividing this by the household size [5, 19].Variation of per capita generation for waste categories across the socioeconomic residential areas and the waste generation was analysed using the General Linear Model (GLM) procedure of Statistical Analysis System (SAS) version 9.1 at $\mathrm{p}<0.05$; while data from the questionnaire was analysed using Statistical Package for Social Sciences (SPSS) and SAS version 9.1.

\section{RESULTS AND DISCUSSIONS}

\subsection{Variation of Waste Generation in Relation with Socioeconomic Characteristics}

The results showed that higher educational level and a job source with a high income earning potential could influence the composition of waste generated in Kumba municipality (Tables 3a, 3b and Table 4). Previous studies showed that educational attainment enhanced the earning potentials of individuals, improved the quality of life and subsequently influenced the quality and quantity of waste generated $[2,6,7,19,24,25]$. 
Table 3(a). Educational level of respondents following area of residence.

\begin{tabular}{|c|c|c|c|}
\hline \multirow{2}{*}{ Educational level of respondents } & \multicolumn{3}{|c|}{ Residential area (\%) } \\
\hline & Low income & Medium income & High income \\
\hline FSLC and below & 85 & 35 & 12 \\
\hline GCE Ordinary Level & 7.5 & 30 & 23 \\
\hline GCE Advanced Level & 7.5 & 30 & 27 \\
\hline University degree & 0 & 5 & 38 \\
\hline Total & 100 & 100 & 100 \\
\hline
\end{tabular}

Table 3(b). Proportion of distribution of job categories of respondents across residential area.

\begin{tabular}{|l|c|c|}
\hline \multirow{2}{*}{ Job categories } & \multicolumn{2}{|c|}{ Job distribution following residential area (\%) } \\
\cline { 2 - 4 } & Low income & Medium income \\
\hline Small farmer/trader & 77 & 26 \\
\hline Large scale farmer/trader & 10 & 13 \\
\hline Employed by private/organisation & 8 & 38 \\
\hline Employed by government & 5 & 13 \\
\hline Self employed & 0 & 38 \\
\hline Total & 100 & 37 \\
\hline
\end{tabular}

Table 4. Generation of waste categories across residential area.

\begin{tabular}{|l|c|c|c|}
\hline \multirow{2}{*}{ Waste categories } & \multicolumn{3}{|c|}{ Waste generation (g/person/day) } \\
\cline { 2 - 4 } & Low income & Medium income & High income \\
\hline Putrescible* & $207.6 \pm 29.6$ & $198.5 \pm 30.7$ & $134.9 \pm 30.7$ \\
\hline Plastics* & $5.5 \pm 3.3$ & $18.8 \pm 3.5$ & $4.2 \pm 3.5$ \\
\hline Metals* & $1.0 \pm 0.9$ & $5.0 \pm 0.8$ & $6.1 \pm 0.8$ \\
\hline Papers* & $1.4 \pm 0.8$ & $2.5 \pm 0.8$ & $4.9 \pm 0.8$ \\
\hline Glass* & $0.9 \pm 0.7$ & $5.8 \pm 1.2$ & $4.9 \pm 1.2$ \\
\hline Textiles & $4.3 \pm 1.1$ & $18.0 \pm 4.5$ & $5.6 \pm 4.5$ \\
\hline Miscellaneous* & $22.1 \pm 4.3$ & $250.8 \pm 42.5$ & $178.0 \pm 42.5$ \\
\hline Total (g/person/day) & $242.8 \pm 40.7$ & & \\
\hline
\end{tabular}

*Waste generation is statistically different $(\mathrm{p}<0.05)$ across socioeconomic residents

The variation of putrescible waste with income in Table $\mathbf{4}$, confirms the results in Tables $\mathbf{3 a}$ and $\mathbf{3 b}$ that low and medium income residents are more involved in farming activities with their wastes characterised by more of putrescible wastes such as peelings of cassava, cocoyam, plantains, bananas and vegetable materials among others, as compared to high income residents. High income residents who are employed by the government and private organizations and less involved in farming activities (Table $\mathbf{3 b}$ ), probably consumed more comestibles than low income residents.

The variation in miscellaneous waste (predominantly sand, ash and dust) could be due to the presence of unpaved yards and subsequently sand in sweepings and the overdependence on fuel wood and charcoal as a source of energy by low and medium income residents. It was observed that most of the high income residents had paved yards or wellshaped grass surfaces and used cooking gas as fuel, hence a substantial reduction in miscellaneous.

The positive correlation between synthetic materials (except textiles) with income could be attributed to the consumption of more packaged foods and the quick to use and quick to dispose habit which develops with affluent lifestyle. These consumer products could be canned drinks and food, plastic drinks and other items which come with packaging. These products could be relatively expensive and not always afforded by low income residents. In addition, the high proportion of papers in high income residents could be due to paper from packaging and a low level of recycling among high income residents. The lack of differences in the generation of textile wastes across socioeconomic levels could be attributed to the fact that low cost clothing and other textile materials are always available in the local markets.

The waste density tends to decrease with increasing income (Table 5) and could be attributed to the significant proportion of putrescible waste, sand, ash and dust in low income residents. Similar findings to the results in the current 
paper have been reported by [26] in Kano metropolis, Nigeria who found that food waste, ash and dirt were inversely related to income and were different across socioeconomic residents while the generation of non-biodegradables (paper, cardboard, textile, rubber, plastic, metal, and glass) were directly related to income and were different across the residents. In a related study, waste components except for food waste and ash were positively related to income level in Eskisehir city, Turkey [27]. The findings that average per capita waste generated in the municipality was not different across socioeconomic levels within the entire study period agree with similar studies in developing countries [28, 29]. This could be attributed to the overall low level of economic development.

Table 5. Descriptive statistics of MSW density across residential area.

\begin{tabular}{|l|c|c|c|}
\hline \multirow{2}{*}{ Item } & \multicolumn{3}{|c|}{ Residential area } \\
\cline { 2 - 4 } & Low income & Medium income & High income \\
\hline Number of persons & 166 & 136 & 175 \\
\hline Number of days & 51 & 44 & 175 \\
\hline Total waste $(\mathrm{kg})$ & 1692 & 1399 & 1418 \\
\hline Total volume $\left(\mathrm{m}^{3}\right)$ & 6.69 & 6.08 & 6.45 \\
\hline Density $\left(\mathrm{Kg} / \mathrm{m}^{3}\right)$ & 252.91 & 230.10 & 219.84 \\
\hline
\end{tabular}

The high proportion of putrescible waste, predominantly food waste generated in Kumba which falls within the range 84 to $88 \%$ for LIRA, 78 to $81 \%$ for MIRA and 75 to $77 \%$ for HIRA is typical for waste management studies in developing countries $[2,19,26]$. This high proportion of putrescible waste implies an increased potential to generate biogas for cooking. Among the different types of biodegradable wastes, food waste holds the highest potential of economic exploitation as it consists of high amount of carbon in the volatile solids that can be converted into biogas [30]. The high proportion of sand, ash and dust which predominates the miscellaneous waste is also typical of low income residents in developing countries $[2,19]$. This proportion has implication on the types of vehicles for waste collection as sand, dust and ash are abrasive and could wear out the sliding parts and expose hydraulic components of compactor trucks.

Furthermore, the increasing composition of non-biodegradable wastes with income has implications for the deployment of recycling options in the future. Recycling conserves resources and energy. For example [31], reported that recycling 0.907 tonnes of paper would save $30.8 \mathrm{~m}^{3}$ of water, $15-17$ trees, provide energy to power an average American home for six months and reduce greenhouse gas emissions by one metric ton of carbon equivalent.

\subsection{Waste Generation in Relation to Household Size}

The present findings which showed that there was no difference in the total per capita waste generation across socioeconomic levels of residents (Table 4) agrees with work by [28, 29]. However, it contrasts earlier studies relating household size and income to waste generated; total waste generation increases with income [2, 6, 11]. [6] showed that as the number of household occupants increase, waste generation per person rather decrease mainly because of economies of scale in the consumption of goods and packaging in the developing countries.

The proportion of biodegradable content of waste generated in developing countries is higher than that generated in developed countries; however, the total amount of biodegradable waste remains highest in high income economies [4, 9]. This study suggests that the lower generation of biodegradable (putrescible) waste in high income residents and the level of development of the community could have contributed to the insignificant difference in the per capita waste generation across socioeconomic residents.

\subsection{Spatial and Temporal Variation of Waste Generation}

This study showed that waste generation did not vary in different periods within the same residential area (Fig. 1) suggesting that the general low level of economic development influenced the purchasing power; hence consumption was not affected by activities across the period. The difference in waste generation across socioeconomic levels of residents within the same period could be attributed to variation in waste categories. This variation has implication for resource allocation and collection frequency by the management authority. This is in conformity with the notion that waste stream varies with location in a municipality, hence management strategies should preferably also vary with waste stream [11, 32]. 


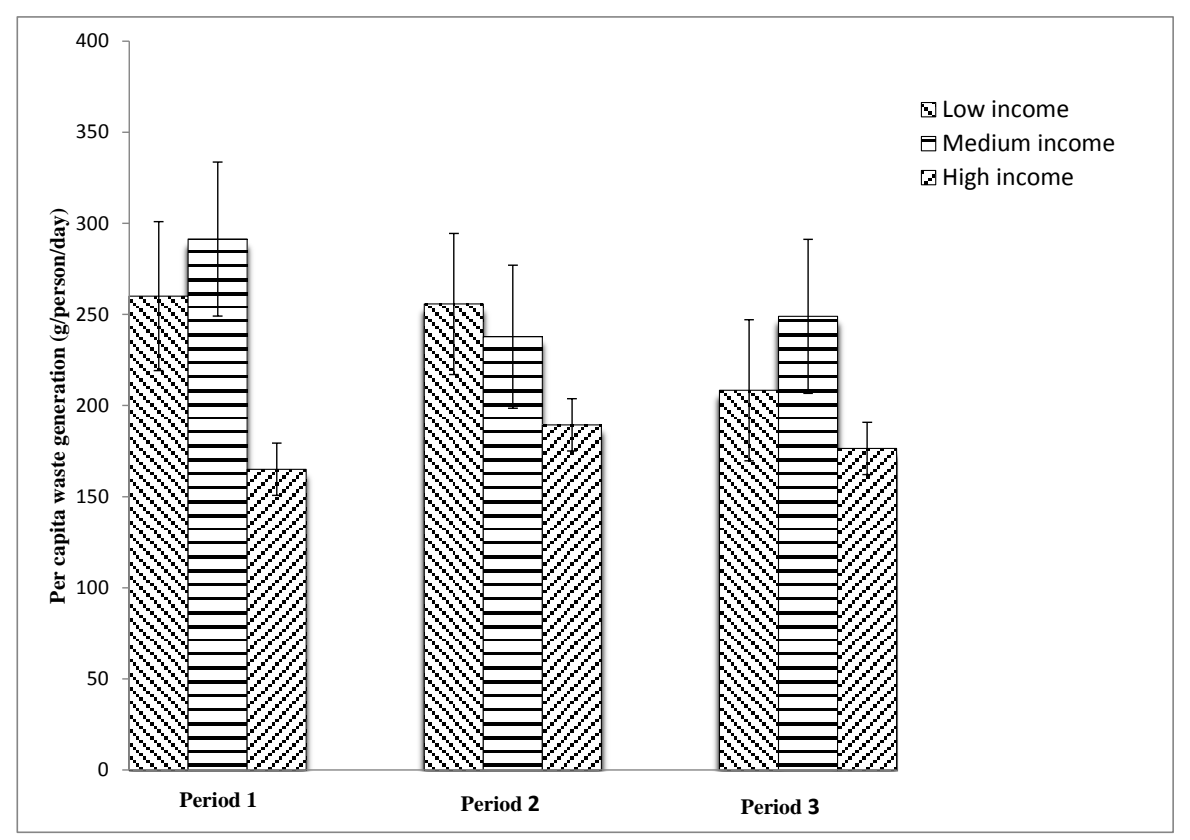

Fig. (1). Per capita waste generation in time and space. Period 1 (week $1 \& 2$ ): $6^{\text {th }}$ to $17^{\text {th }}$ December 2013 - before Christmas; Period 2 (week 3, $4 \& 5$ ): $18^{\text {th }}$ December 2013 to $7^{\text {th }}$ January 2014 - within Christmas; Period 3 (week 6, $7 \& 8$ ): $8^{\text {th }}$ to $28^{\text {th }}$ January $2014-$ after Christmas.

\subsection{Waste Management Practices and Community Participation for Sustainability}

The present study found that the waste collection service providers, the city council, were irregular and the low income residence were totally omitted due to financial constraints (Tables 6 and 7). Considering that the bulk of waste is putrescible and produced mainly by low income residents, a total omission of this stratum of the community will mean huge amounts of waste will be abandoned. Following this limitation, households indiscriminately disposed wastes in ways that could hamper environmental health (Table 8).

Table 6. View of residents on the frequency of passage of refuse van.

\begin{tabular}{|l|c|c|c|}
\hline \multirow{2}{*}{ Passage frequency } & \multicolumn{3}{|c|}{ Residential area (\%) } \\
\cline { 2 - 4 } & Low income & Medium income & High income \\
\hline Once in 3 days & 0 & 13 & 4 \\
\hline Once in 7 days & 0 & 4 & 11 \\
\hline Once in 14 days & 0 & 31 & 27 \\
\hline Once after 14 days & 0 & 52 & 46 \\
\hline Never passes & 100 & 0 & 12 \\
\hline Total & 100 & 100 & 100 \\
\hline
\end{tabular}

Table 7. View of residents on status of bin level upon the passage of refuse van.

\begin{tabular}{|c|c|c|c|c|c|}
\hline \multirow{2}{*}{ Residential area (\%) } & \multicolumn{5}{|c|}{ Opinion on bin level } \\
\hline & Half full & Always full & Always overflows & Empty & Total \\
\hline Medium income & 22 & 13 & 65 & 0 & 100 \\
\hline High income & 21 & 25 & 50 & 4 & 100 \\
\hline Total* & 21 & 19 & 58 & 2 & 100 \\
\hline
\end{tabular}

*Total proportion for each column

A large proportion of households were found willing to participate in waste sorting with available incentives (Table 9). It was also found that a highly significant proportion of respondents (77\%) were not educated on MSW management $\left(\mathrm{X}^{2}=9.41 ; \mathrm{df}=2 ; \mathrm{P}<0.01\right)$ and the level of awareness seemed to increase with increasing level of income (Table 10). This finding agrees with previous studies that financial constraints and lack of policy implementation threatens waste management in most cities in the developing world resulting to indiscriminate waste disposal $[14,18,20]$. Furthermore, 
incentives and public awareness enhances community participation in the recovery of MSW, its values and sustainability in the management $[8,14,33]$. The situation in Kumba could be improved if community participation is enhanced to recover and market the values embedded in MSW.

Table 8. Proportion of residents using the various waste disposal sites.

\begin{tabular}{|l|c|c|c|}
\hline \multirow{2}{*}{ Disposal site } & \multicolumn{3}{|c|}{ Residential area (\%) } \\
\cline { 2 - 4 } & Low income & Medium income & High income \\
\hline Refuse van & 0 & 78 & 54 \\
\hline Hole & 50 & 9 & 22 \\
\hline Open space/bushes & 69 & 13 & 8 \\
\hline Aquatic & 0 & & 23 \\
\hline
\end{tabular}

Table 9. Basis under which households were willing to participate in the sorting of MSW.

\begin{tabular}{|l|c|c|c|c|}
\hline \multirow{2}{*}{ Residential area (\%) } & \multicolumn{3}{|c|}{ Basis for participation on waste sorting } \\
\cline { 2 - 5 } & Unwilling & Participate with incentives & Unconditional & Total \\
\hline Low income & 12 & 42 & 46 \\
\hline Medium income & 26 & 22 & 52 & 100 \\
\hline High income & 23 & 27 & 100 & 50 \\
\hline Total* & 20 & 31 & 49 \\
\hline
\end{tabular}

Table 10. Awareness situation of respondents on MSW management.

\begin{tabular}{|c|c|c|c|}
\hline \multirow{2}{*}{ Residential area (\%) } & \multicolumn{3}{|c|}{ Responses } \\
\cline { 2 - 4 } & Yes & No & Total \\
\hline Low income & 8 & 92 & 100 \\
\hline Medium income & 17 & 83 & 100 \\
\hline High income & 42 & 58 & 100 \\
\hline Total & 23 & 77 & 100 \\
\hline
\end{tabular}

*Total proportion for each column

\section{CONCLUSION}

The quest for a wealthy lifestyle is influencing the composition of solid waste stream across socioeconomic levels in Kumba municipality. Irrespective of the income level of the residential area, municipal solid waste was predominantly putrescible, made up of remains of organic food stuffs constituting more than $75 \%$ of the waste stream. This reflects an overall low income level which is typical of a developing country. The management authority could envisage a bottomup approach for sustainable MSW management through resource recovery for energy following the available proportion of biodegradable waste to remedy the financial stress in providing infrastructural needs.

\section{CONFLICT OF INTEREST}

The authors confirm that this article content has no conflict of interest.

\section{ACKNOWLEDGEMENTS}

We would like to thank the Director of SWECOM Cable Network for Mamfe and Muyuka for funding this project and the Government Delegate of Kumba City Council for his material and moral assistance. Technical support from BUST is highly appreciated.

\section{REFERENCES}

[1] L. Adogame, "Toward Enhanced Public-Private Partnership in Solid Waste Management in Lagos State", Paper Presented at the Workshop on Effective Solid Waste Management, Lagos Airport Hotel, Ikeja, Nigeria, 2009.

[2] A.A. Amori, B.O. Fatile, S.O. Ihuoma, and H.O. Omeregbee, "Waste generation and management practices in residential areas of nigerian tertiary institutions", Journal of Educational and Social Research, vol. 3, no. 4, pp. 45-52, 2013.

[3] Q.H. Bari, K. Mahbub Hassan, and R. Haque, "Scenario of solid waste reuse in Khulna city of Bangladesh", Waste Management, vol. 32, no. 12, pp. 2526-2534, 2012. 
[http://dx.doi.org/10.1016/j.wasman.2012.07.001] [PMID: 22871492]

[4] D. Hoornweg, and P. Bhada-Tata, "What a waste: A global review of solid waste management", The World Bank. Urban Development Series Knowledge Paper No. 15, 2012.

[5] L.O. Mbeng, P.S. Phillips, and R. Fairweather, "Waste characterisation as an element of household waste management operations: A case study in limbe, Cameroon", Open Waste Management Journal, vol. 5, pp. 49-58, 2012.

[http://dx.doi.org/10.2174/1876400201205010049]

[6] H.A. Abu -qdais, M.F. Hamoda, and J. Newham, "Analysis of residential solid waste at generation sites", Waste Management \& Research, vol. 15 , pp. 395-406, 1997.

[http://dx.doi.org/10.1177/0734242X9701500407]

[7] A.D. Emery, A.J. Griffiths, and K.P. Williams, "An in depth study of the effects of socio-economic conditions on household waste recycling practices", Waste Management \& Research, vol. 21, no. 3, pp. 180-190, 2003 [http://dx.doi.org/10.1177/0734242X0302100302] [PMID: 12870638]

[8] Y. Dhokhikah, and Y. Trihadiningrum, "Solid waste management in asian developing countries", Journal of Applied Environmental and Biological Sciences, vol. 2, no. 7, pp. 329-335, 2012.

[9] UNEP, Solid Waste Management, vol. 1, 2014. Available from: http://www.unep.org/ietc/Portals/136/SWM-Vol1-Part1-Chapters1to3.pdf

[10] R. Adjia, W.M. Fezeu, J.B. Tchatchueng, S. Sorho, G. Echevarria, and M.B. Ngassoum, "Long term effect of municipal solid waste amendment on soil heavy metal content of sites used for periurban agriculture in ngaoundere, Cameroon", African Journal of Environmental Sciences and Technology, vol. 2, no. 12, pp. 412-421, 2008.

[11] B.B. Babatunde, I.F. Vincent-Akpu, G.N. Woke, E. Atarhinyo, U.C. Aharanwa, A.F. Green, and O. Isaac-Joe, "Comparative analysis of municipal solid waste (MSW) composition in three local government areas in rivers state, Nigeria", African Journal of Environmental Science and Technology, vol. 7, no. 9, pp. 874-881, 2013.

[12] S. Esakku, K. Palanivelu, and J. Kurian, "Assessment of heavy metals in a municipal solid waste dumpsite", Workshop on Sustainable Landfill Management held in Chennai, India from 3-5 December , pp. 139-145, 2003.

[13] Women in Europe for a Common Future (WECF), 2004/2005, "Dangerous Health Effects of Home Burning of Plastics and Waste.Fact Sheet.", 2014. Available: http://minerals.usgs.gov/minerals/pubs/myb.html

[14] L. Parrot, J. Sotamenou, and B.K. Dia, "Municipal solid waste management in Africa: strategies and livelihoods in Yaoundé, Cameroon", Waste Management, vol. 29, no. 2, pp. 986-995, 2009. [http://dx.doi.org/10.1016/j.wasman.2008.05.005] [PMID: 18656342]

[15] UNEP, Developing Integrated Solid Waste Management Plan: Training Manual, "Waste Characterisation and Quantification with Projects for Future", vol. 1, 2009.

[16] E. Achankeng, "Globalisation, Urbanisation and Municipal Solid Waste Management in Africa", In: African Studies Association of Australasia and the Pacific, 2003 Conference Proceedings - Africa on a Global Stage, 2014. Available from: https:/www.scribd.com/ doc/41886755/Achankeng-Globalization-Urbanization-and-MSW-Mgmt-in-Africa

[17] J. Kurian, and R. Nagendran, "Top down and bottom up approach for sustainability of waste management in developing countries", In: Eleventh International Waste Management and Landfill Symposium, S. Margherita di Pula, Caghari, Italy, 2007, pp. 1-5.

[18] V.E. Manga, O.T. Forton, and A.D. Read, "Waste management in Cameroon: A new policy perspective?", Resources, Conservation and Recycling, vol. 52, pp. 592-600, 2008. [http://dx.doi.org/10.1016/j.resconrec.2007.07.003]

[19] A.S. Oberlin, "Characterisation of household waste in kinondoni municipality, dar es salaam", Academic Journal of Interdisciplinary Studies, vol. 2 , no. 13 , pp. $35-46,2013$.

[20] T.Ch. Ogwueleka, "Municipal solid waste characteristics and management in Nigeria, Iran", Journal of Environmental Health Science and Engineering, vol. 6, no. 3, pp. 173-180, 2009.

[21] B. Bolaane, and M. Ali, "Sampling household waste at source: lessons learnt in Gaborone", Waste Management \& Research, vol. 22, no. 3, pp. 142-148, 2004. [http://dx.doi.org/10.1177/0734242X04044970] [PMID: 15253497]

[22] Cascadia, “Guidelines for Waste Characterisation Studies in the State of Washington”. Washington State Department of Ecology 2013. Available from: https://www.recycle.ab.ca/uploads/File/pdf/WasteCharFinalReport.pdf

[23] V. Gawaikar, and V.P Deshpande, "Source specification, quantification and characterisation of municipal solid waste - A review", In: Solid Waste Management Division, National Environmental Engineering Research Institute (NEERI): Nagpur 440020, 2006.

[24] D. Bloom, D. Canning, and K. Chan, "Higher Education and Economic Development in Africa". Human Development Sector, African Region, 2006. Available: http://ent.arp.harvard.edu/AfricaHigherEducation/Reports/BloomAndCanning.pdf

[25] A. M. Njong, "The effects of educational attainment on poverty reduction in Cameroon", Journal of Education, Administration and Policy Studies, vol. 2, no. 1, pp. 001-008, 2010.

[26] A.B. Nabegu, "Application of one way analysis of variance in exploring municipal solid waste characteristics in kano, metropolis, northwestern Nigeria", Greener Journal of Science, Engineering and Technology Research, vol. 3, no. 2, pp. 62-67, 2013. 
[27] M. Banar, and A. Özkan, "Characterisation of the municipal solid waste in eskisehir city Turkey", Environmental Engineering Science, vol. 25, no. 8, pp. 1213-1219, 2008. [http://dx.doi.org/10.1089/ees.2007.0164]

[28] G. Bernache-Pérez, S. Sánchez-Colón, A.M. Garmendia, A. Dávila-Villarreal, and M.E. Sánchez-Salazar, "Solid waste characterisation study in the Guadalajara Metropolitan Zone, Mexico", Waste Management and Research, vol. 19, no. 5, pp. 413-424, 2001. [http://dx.doi.org/10.1177/0734242X0101900506] [PMID: 11954727]

[29] G. Gómez, M. Meneses, L. Ballinas, and F. Castells, "Seasonal characterization of municipal solid waste (MSW) in the city of Chihuahua, Mexico", Waste Management, vol. 29, no. 7, pp. 2018-2024, 2009. [http://dx.doi.org/10.1016/j.wasman.2009.02.006] [PMID: 19303762]

[30] R. K. Somashekar, "Potential of biogas production from food waste in a uniquely designed reactor under laboratory conditions", International Journal of Geology, Agriculture and Environmental Sciences, vol. 2, no. 2, pp. 001-007, 2014.

[31] National Energy Education Development (NEED), 2012/2013. , Mueum of of Solid Waste and Energy. The NEED Project P.O Box 10101, VA 20108., 2014. Available: www.need.org/files/curriculum/guides/museum of solid waste.pdf

[32] A.B. Nabegu, and A. Mustapha, "Using pearson product moment correlation to explore the relationship between different categories of municipal solid waste in kano metropolis, north-western Nigeria", Journal of Environment and Earth Science, vol. 2, no. 4, pp. 63-67, 2012.

[33] L.A. Guerrero, G. Maas, and W. Hogland, "Solid waste management challenges for cities in developing countries", Waste Management, vol. 33, no. 1, pp. 220-232, 2013.

[http://dx.doi.org/10.1016/j.wasman.2012.09.008] [PMID: 23098815]

(C) Tambe et al.; Licensee Bentham Open

This is an open access article licensed under the terms of the Creative Commons Attribution-Non-Commercial 4.0 International Public License (CC BY-NC 4.0) (https://creativecommons.org/licenses/by-nc/4.0/legalcode), which permits unrestricted, non-commercial use, distribution and reproduction in any medium, provided the work is properly cited. 